\title{
2. LITHOSTRATIGRAPHY AND PALEOENVIRONMENTS OF THE ISLAND BEACH BOREHOLE, NEW JERSEY COASTAL PLAIN DRILLING PROJECT ${ }^{1}$
}

\author{
James P. Owens, ${ }^{2}$ Kenneth G. Miller, ${ }^{3,4}$ and Peter J. Sugarman ${ }^{5}$
}

\begin{abstract}
We present lithostratigraphic and paleoenvironmental interpretations of the Island Beach borehole. This borehole provides the only Upper Cretaceous to lower Eocene section recovered by the New Jersey Coastal Plain Drilling Project (Ocean Drilling Program Leg 150X). Upper Cretaceous and Paleogene sections were deposited in relatively deep marine paleoenvironments (typically outer middle to outer neritic; 50-200 m paleowater depths) as a series of upsection shallowing sequences. Although the Oligocene section is relatively thick $(267 \mathrm{ft}[81.4 \mathrm{~m}]$ ), it is poorly fossiliferous and provides the most equivocal Oligocene paleoenvironmental record of the three Leg 150X boreholes. Lower Miocene strata at this site consist of three poorly fossiliferous sequences (Kw1a, K1b, and Kw2a) deposited in shallow marine (inner neritic, near-shore, prodelta, and delta front) to fluvial environments. The Miocene sections also shallow upsection, both within sequences and within the Miocene as a whole. The surficial strata at Island Beach are composed of uppermost Pleistocene (?) to Holocene deposited as one deepening-upward succession representing fluvial to near-shore deposits.

Tectonics progressively reshaped the basins in which Upper Cretaceous to Holocene strata were deposited. For example, Oligocene basins were mainly in southern New Jersey (Atlantic City and south), whereas the early Miocene Kirkwood basin was more expansive both updip and along strike to the north. Tectonic changes resulted in differential beveling of stratigraphic units and preferential preservation. For example, the lower Oligocene appears to be truncated north of Mays Landing, NJ, and is poorly represented at the Island Beach borehole.
\end{abstract}

\section{INTRODUCTION}

The Tertiary stratigraphy along the coast of New Jersey was investigated in three boreholes drilled at Island Beach, Atlantic City, and Cape May by the New Jersey Coastal Plain Drilling Project, Ocean Drilling Program (ODP) Leg 150X (Miller, et al., 1994; Miller et al., 1996). This investigation is the first stage of a larger study to link the onshore record with the offshore stratigraphy found in the slope boreholes drilled by ODP Leg 150 (Mountain, Miller, Blum, et al., 1994) and a transect of boreholes that will be drilled at a later date across the shelf (see Miller, Chapter 1, this volume).

Age control is provided by biostratigraphy for Upper Cretaceous to Paleocene strata, by magnetobiostratigraphy for Eocene strata, by biostratigraphy and Sr-isotopic stratigraphy for Oligocene to Miocene strata, and by radiocarbon ages for the Holocene section (Miller, et al., 1994; M.-P. Aubry in Miller, et al., 1994; Browning et al., Chapter 17, this volume; Liu et al., Chapter 10, this volume; Pekar et al., Chapter 15, this volume). Depositional environments were inferred in this paper from the lithofacies; this is supplemented by benthic foraminiferal studies elsewhere in the volume (Browning et al., Chapter 16, this volume). Some additional biostratigraphic data were provided by paleontologists of the United States Geological Survey (Bybell and Self-Trail, Chapter 9, this volume). In addition to the Leg 150X sites, continuously cored material is provided by the ACGS\#4 borehole (Mays Landing), 13 km inland from the coast (Owens et al., 1988) and a borehole at Allaire State Park (Sugarman

'Miller, K.G., and Snyder, S.W. (Eds.), 1997. Proc. ODP, Sci. Results, 150X: College Station, TX (Ocean Drilling Program).

${ }^{2}$ U.S. Geological Survey, Reston, VA 20192, U.S.A. (Deceased)

'Department of Geological Sciences, Rutgers University, Piscataway, NJ 08855 , U.S.A. kgm@rci.rutgers.edu U.S.A.

Lamont-Doherty Earth Observatory, Columbia University, Palisades, NY 10964,

${ }^{5}$ New Jersey Geological Survey, CN 427, Trenton, NJ 08625, U.S.A. et al., 1991; Figs. 1,2). These holes provide an updip view of the formations that complements the downdip view of Leg 150X.

A major scientific objective of the onshore study was to evaluate the effects of eustasy (global sea level) vs. tectonics on the stratigraphic record. Olsson (1991) and Miller et al. (1996) summarized the effects of eustatic change on the New Jersey Margin. Although this passive margin has been influenced by eustatic change, tectonics also played a major role in shaping its stratigraphic record. Owens and co-authors (Owens, 1970, 1983; Owens and Gohn, 1985; Owens et al., 1968, 1970, 1977) argued that the basins and arches on the margin (Fig. 1) are caused by warping at different places at different times: the so-called "rolling basin concept." For example, the Salisbury Embayment (Fig. 1) may record progressive downwarping to the south as indicated by a shift from an early Miocene depocenter in New Jersey to a late Miocene depocenter in Maryland (Owens et al., 1988). Evaluation of the rolling basin concept requires an accurate reconstruction of the basins through the Tertiary. The data from the three Leg 150X boreholes, the ACGS\#4 borehole, and partially cored holes elsewhere in southern New Jersey can be used to reconstruct basinal changes during the Cenozoic. Undisturbed samples from these holes were used to establish the environment of deposition within different parts of the basin.

The Island Beach borehole is the northernmost of the three Leg 150X sites. The hole was drilled on the southern end of the barrier island that makes up the state park. The hole was spudded in at $12 \mathrm{ft}$ (3.7 m) above sea level and drilled to a depth of $1223 \mathrm{ft}$ (372.9 m; all depths are given below land's surface). This hole was the only one to reach Cretaceous strata. Core recovery was $86.7 \%$. Miller et al. (1994) provided preliminary lithostratigraphic descriptions, identification of the formations, and delineation of the sequences. This study re-evaluated the lithostratigraphy by redescribing the general sediment types (textures and structures) and stratigraphic contacts, examining the sediments using a binocular microscope for mineralogy and texture, conducting heavy mineral separations for opaque and nonopaque minerals, and analyzing the clay minerals using an X-ray dif- 


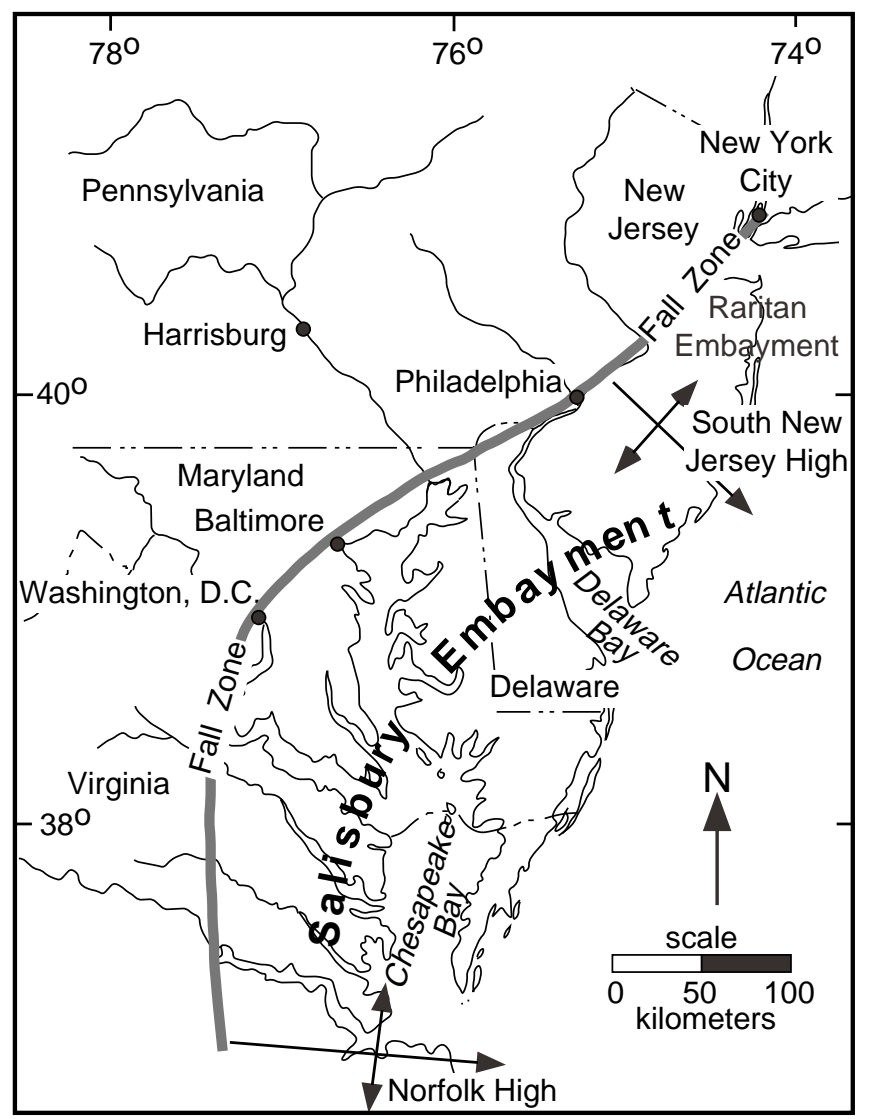

Figure 1. Location map of the middle Atlantic coastal plain showing depositional embayments (basins) and highs (arches). Modified after Pazzaglia (1993).

fractometer (for clay mineralogy data tables, see Van Valkenburg et al., this volume).

\section{CRETACEOUS FORMATION}

\section{Undifferentiated Red Bank-Navesink Formations}

The oldest formation in this hole, the undifferentiated Red BankNavesink Formations, occurs between $1185 \mathrm{ft}(361.3 \mathrm{~m})$ and total depth (Fig. 2). The unit is a dark brownish black, massive, extensively bioturbated, very silty and clayey fine- to medium-grained quartz $(10 \%-25 \%)$ glauconite sand. No whole macrofossils are present, but calcareous microfossils are common. Finely crystalline pyrite is a common constituent in these beds. The lower $6 \mathrm{ft}(1.8 \mathrm{~m})$ of the formation has a much more calcareous matrix than above. The base of the formation was not reached, but in nearby holes this unit is unconformable with the underlying unit and is unconformably overlain by the Hornerstown Formation. Both unconformities are associated with phosphate-glauconite lag deposits that cause large spikes in gammaray geophysical logs throughout most of the coastal plain.

Petrology: Only the clay minerals were analyzed in this formation. Interlayered illite/smectite is by far the dominant clay mineral with lesser amounts of illite. Kaolinite is present in trace amounts. Kaolinite is a more common constituent in this unit in updip areas.

Environment of deposition: We interpret a middle to outer neritic depositional environment for the Red Bank-Navesink Formations based on high clay and silt content, medium to high concentrations of glauconite sand, absence of large shells, common microfauna, massive bedding caused by bioturbation, and low concentrations of kaolinite. This interpretation is supported by benthic foraminiferal biofacies studies at other boreholes, which indicate outer neritic deposition (e.g., Olsson, 1991).

Age and correlation: The occurrence of Hedbergella monmouthensis indicates that the section is uppermost Maastrichtian, although the absence of marker taxa precludes a foraminiferal zonal assignment (Liu et al., Chapter 10, this volume). Zonal assignment of the undifferentiated Red Bank-Navesink Formations was determined primarily with calcareous nannofossils. Samples from 1188.6 to $1195.9 \mathrm{ft}$ (362.4-364.6 m) fall with the Nephrolithus frequens Zone (= CC26). Samples from 1199 to $1221 \mathrm{ft}(365.5-772.3 \mathrm{~m})$ fall within the Lithraphidites quadratus Zone $(=\mathrm{CC} 25$; D. Bukry in Miller, et al., 1994). The undifferentiated Red Bank-Navesink Formations at Island Beach is upper Maastrichtian and correlates with the Navesink (Zone CC25) and Red Bank (Zone CC26) Formations in outcrop. The formation at Island Beach is considered a condensed section because of its relative thinness compared to its age equivalents in outcrop and age range.

\section{PALEOGENE FORMATIONS}

There are seven Paleogene formations in the Island Beach borehole: Hornerstown, Vincentown, Manasquan, Shark River, the newly named upper Eocene Absecon Inlet (Browning et al., Chapter 18, this volume), the newly named Oligocene Sewell Point (Pekar et al., Chapter 8, this volume), and the newly named upper Oligocene Atlantic City (Pekar et al., Chapter 8, this volume) Formations (Fig. 2).

\section{Hornerstown Formation}

The oldest Tertiary formation in New Jersey is the Hornerstown, which occurs between 1167 and $1185 \mathrm{ft}(355.7$ and $361.2 \mathrm{~m})$ in this hole (Fig. 2). This unit has more varied lithofacies than the underlying Cretaceous units. The lower $2 \mathrm{ft}(0.6 \mathrm{~m})$ was not recovered and the contact with the underlying Red Bank-Navesink Formation is placed at $1185 \mathrm{ft}(361.3 \mathrm{~m})$ based on the downhole gamma-ray log (Fig. 2). The overlying $5 \mathrm{ft}(1.6 \mathrm{~m})$ is a dark gray to grayish black massive clayey fine- to medium-grained quartz $(10 \%-20 \%)$ glauconite sand. This sand is much darker gray than the underlying Cretaceous sediments. Thus, the K/T boundary was not recovered, and we cannot determine if there is an unconformity at the base, although the absence of Zone P0-P1b (Liu et al., Chapter 10, this volume) and the large gamma-ray spike (Fig. 2) are consistent with an unconformity. No whole macrofossils were observed in these beds, although microfossils are common, as are scattered pieces of dark brown phosphatic material. There is a gradual decrease in glauconite content into the upper beds, accompanied by an increase in fine- to medium-grained mica (white, green, and, less commonly, brown varieties). The upper beds are finely laminated to very thinly bedded. The Hornerstown is unconformably overlain by the Vincentown Formation.

Petrology: Only the clay minerals were investigated. As in the underlying unit, illite/smectite is the dominant mineral, although illite is present in lesser amounts. Kaolinite occurs in trace amounts.

Environment of deposition: Environmental interpretation of this unit follows a pattern noted elsewhere in the coastal plain (Owens and Sohl, 1969; Sugarman et al., 1995). There is a deeper water or more distal glauconite sand at the base that is overlain by a shallower water or more proximal micaceous, well-bedded clay-silt. Therefore, this unit records a partial transgressive/regressive cycle as defined by Owens and Sohl (1969). The Hornerstown Formation was deposited in a middle to outer shelf environment. Miller, et al. (1994) originally used the term "Hornerstown equivalent" for this unit at Island Beach, because the facies found at this borehole are not typical of the Hor- 


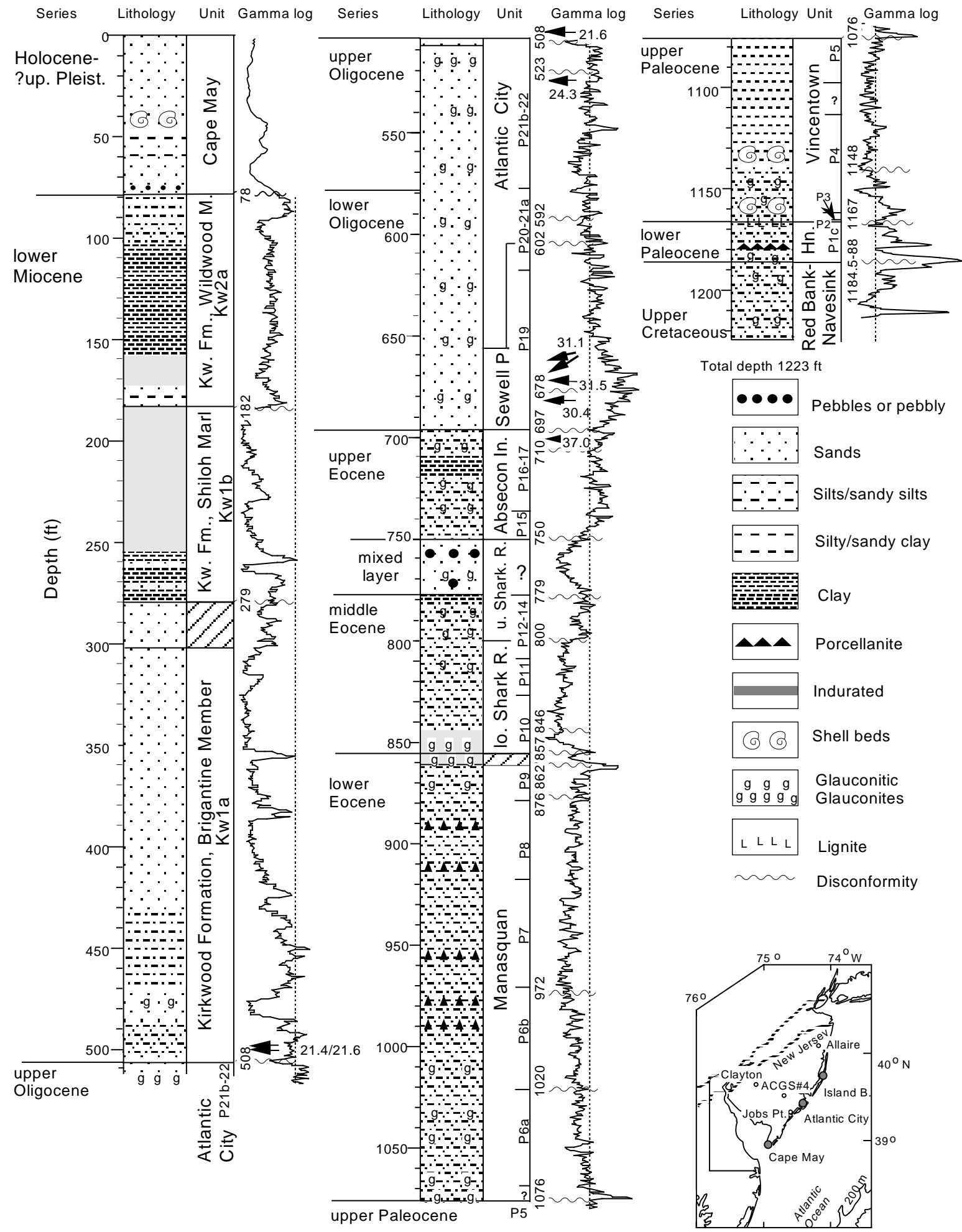

Figure 2. Series, lithostratigraphy, lithostratigraphic units, and gamma logs of the Island Beach borehole. Wavy lines indicate unconformities with depths indicated in feet. The log for the upper $78 \mathrm{ft}$ is the analog New Jersey Geological Survey log; all logs below that are the BPB logs showing a thin dashed line at 100 API units. Numbers with arrows are Sr-isotopic ages in Ma using the Berggren et al. (1995) time scale after Sugarman et al. (Chapter 12, this volume) and Pekar et al. (Chapter 15, this volume). Planktonic foraminiferal zones are after Liu et al. (Chapter 10, this volume). Modified after Miller et al. (1994) and Miller (Chapter 1, this volume). Inset location map shows landward limits of Miocene and Cretaceous strata as stippled lines. Abbreviations: Kw. $=$ Kirkwood; P. $=$ Point; Hn. = Hornerstown; R. = River; $\mathrm{M}=$ Member; $\mathrm{u} .=$ upper; lo. $=$ lower 
nerstown Formation in updip outcrop and subsurface sections because of the lower amounts of glauconite at Island Beach.

Age and distribution: The Hornerstown was dated in this hole using calcareous nannofossils (Zone NP3, L. Bybell, pers. comm., 1994) and planktonic foraminifers (Zone P1c, Liu et al., Chapter 10, this volume). These biostratigraphic data indicate that the unit is lower, but not lowermost, Danian.

\section{Vincentown Formation}

The Vincentown Formation occurs between 1075.5 and $1167 \mathrm{ft}$ (327.9 and $355.7 \mathrm{~m}$ ) in this hole, where it unconformably overlies the Hornerstown Formation along a sharp contact (Fig. 2). The boundary is characterized by small-diameter burrows filled with glauconitequartz sand projecting from the overlying Vincentown Formation into the dark gray clay-silt of the Hornerstown Formation. The lower $34 \mathrm{ft}(10.4 \mathrm{~m})$ of the Vincentown Formation is a massive, bioturbated glauconitic (about $35 \%$ ) clayey quartz sand. The sand is silty, fine- to very fine-grained, and dark gray to dark greenish gray. Both microfossils and macrofossils are common. The brachiopod Oleneothyris harlani is the dominant macrofossil at $1159-1160 \mathrm{ft}(353.4-353.7$ $\mathrm{m}$ ), as it is elsewhere in the lower Vincentown Formation (Owens et al., 1995b). The upper $65 \mathrm{ft}(19.8 \mathrm{~m})$ of the formation is distinctly bedded and lacks glauconite. Bed thickness decreases upward and the upper part of the unit contains finely laminated to very thinly bedded couplets of dark clay and silt to very fine-grained sands. Some of the sands are cross stratified. For the most part, there are no macrofossils and few microfossils in this part of the formation. The Vincentown Formation is overlain unconformably by the Manasquan Formation and is an unconformity-bounded unit.

Petrology: As in the underlying units, only the clay mineralogy was determined for this formation. Illite/smectite is the dominant mineral with lesser amounts of illite. The uppermost beds also contain low amounts of kaolinite. The increase in kaolinite in the upper beds is similar to this level at the updip Clayton borehole, although the concentration is lower at Island Beach (Fig. 2; Gibson et al., 1993). These authors ascribed the kaolinite increase to a marked climatic change near the Paleocene/Eocene boundary. It is interesting that kaolinite can be detected this far downdip.

Environment of deposition: The pattern of deposition in the Vincentown Formation is deeper water sediments at the base (transgressive) and shallower at the top (regressive). The transgressive beds are massive glauconite sands. The presence of sand-sized mica, local large shells, and accordion-shaped glauconite grains all indicate a middle neritic depositional environment for these beds (see facies models in Owens and Sohl, 1969). The transition into the upper nonglauconitic beds accompanied by the fining-upward indicates a shallower depositional environment interpreted as prodelta.

Age and distribution: The Vincentown Formation was dated using calcareous nannofossils and planktonic foraminifers. The lower beds in this unit are assigned to upper Paleocene Zones NP5-NP6 and the upper beds to Zones NP8-NP9 (late Paleocene; Miller, et al., 1994). The planktonic foraminifers indicate that the Vincentown Formation comprises Zones P2-P5 and may be in part upper lower Paleocene (Liu et al., Chapter 10, this volume; Fig. 2). Miller, et al. (1994) and Liu et al. (Chapter 10, this volume) recognize a hiatus associated with a contact at $1148 \mathrm{ft}(350.0 \mathrm{~m})$ based on a facies change and a biostratigraphic break (i.e., Zone NP7 is not represented; Miller, et al., 1994).

The Vincentown Formation at Island Beach is finer grained than it is in the outcrop belt, especially in the upper beds. In outcrop, the upper part of the formation is a fine- to medium-grained quartz sand.

\section{Manasquan Formation}

The Manasquan Formation (855-1075.5 ft [260.7-327.9 m]; Fig. 2) unconformably overlies the Vincentown Formation with a sharp contact marked by a gamma-ray spike (Fig. 2). A 3-ft-thick (0.9 m) dark green fine- to very fine-grained quartz glauconite sand occurs at the base of the Manasquan Formation. The glauconite grains are a very dark green, and the common botryoidal shape is subdued, perhaps indicating wear during transport. Dark brown phosphatic grains and scattered sand-sized mica are also present. The glauconitic sand interval is overlain by $36.5 \mathrm{ft}(11.1 \mathrm{~m})$ of dark green, massive to finely laminated, silty clay. Silt to very fine-grained glauconite and quartz sand are common in the interval. This interval is overlain by 4 $\mathrm{ft}(1.2 \mathrm{~m})$ of fine-grained glauconite quartz sand $(1032-1036 \mathrm{ft}$ [314.6-315.8 m]). The overlying $164 \mathrm{ft}(50.0 \mathrm{~m})$ consist of a dusky yellow-green, massive to very finely laminated clayey silt with a component of very fine-grained quartz glauconite sand. The glauconite grains have rod shapes (spicular glauconite), and foraminifers are common in this interval. In the upper $13 \mathrm{ft}(4.0 \mathrm{~m})$, thin seams of fine- to medium-grained glauconite sand are interbedded with claysilts. Although the Manasquan Formation is an unconformity-bounded unit, four sequences can be recognized within it using integrated stratigraphy (Browning et al. (Chapter 17, this volume).

Petrology: The clay mineral suite in the lower dark green facies is dominated by illite/smectite with lower amounts of illite and kaolinite. Kaolinite is absent in the lighter green facies where the proportions of illite/smectite and illite are the same as in the lower dark green facies. The zeolite clinoptilolite is present in small but persistent amounts in the light green facies.

Environment of deposition: This borehole is important, because it contains the thickest section of the Manasquan Formation recovered in the New Jersey Coastal Plain. Lithofacies characteristics of the Manasquan Formation at Island Beach that indicate distal deposition in the outer neritic zone include massive to finely laminated bedding; common to abundant foraminifers; lack of large megafossils; and dark green color at the base, gradually becoming lighter green up through the section. The presence of thin fine to medium quartz glauconite sand stringers and the persistence of quartz and glauconite silt to very fine sand in the clay-silts may indicate deposition was not outermost neritic or bathyal. The outer neritic Manasquan Formation represents a deeper depositional environment than the underlying Vincentown Formation and overlying Shark River Formation.

Age and distribution: The age of this unit was determined using calcareous nannofossils, planktonic foraminifers, and magnetostratigraphy (see Browning et al., Chapter 17, this volume for integrated magnetobiostratigraphy). The lower part of the Manasquan Formation falls within Zone NP10, which is lowermost Eocene (M.-P. Aubry in Miller, et al., 1994; Bybell and Self-Trail, Chapter 9, this volume). This contrasts with the situation at Clayton (Fig. 2), where the basal Manasquan Formation spans Zones NP9-NP10 and the Paleocene/Eocene boundary (Gibson et al., 1993). The initial reports from this borehole (Miller, et al., 1994) indicated that the basal Manasquan Formation at Island Beach may have also contained some of Zone NP9. Subsequent studies show that the marker for the base of Zone NP10 extends to the base of the Manasquan at Island Beach, indicating that it is Eocene (Bybell and Self-Trail, Chapter 9, this volume; M.-P. Aubry, pers. comm., 1995). Nevertheless, there are indications that the basal Manasquan at this site is uppermost Paleocene, as it contains the benthic foraminifer Stensioina beccariiformis (Pak et al., Chapter 23, this volume). Further study of this intriguing discrepancy is warranted. In any case, the presence of a thin glauconite sand with scattered phosphatic debris in the base of the Manasquan, the burrowed contact between this unit and the underlying Vincentown Formation, and the gamma spike on the geophysical logs indicate that some section is missing at the Manasquan/Vincentown contact. Other than noted above, the Manasquan Formation is lower Eocene (Zones NP10-NP13; P6-P9; Miller, et al., 1994; Liu et al., Chapter 10, this volume).

The Manasquan Formation only crops out where the overlying beds have been extensively stripped away along the Manasquan Riv- 
er in the northern coastal plain and along the Rancocas drainage in the west central New Jersey coastal plain. The lower Manasquan Formation has a large clastic medium to coarse sand component near Pemberton, NJ, in the central coastal plain. Thus, the Manasquan Formation may be partly inner neritic in some of the updip outcrop areas.

\section{Shark River Formation}

The Shark River Formation occurs between $750 \mathrm{ft}(228.7 \mathrm{~m})$ and 857 or $862 \mathrm{ft}$ ( 261.3 or $262.8 \mathrm{~m}$ ) in this hole (Fig. 2). A thin bed (1.3 $\mathrm{ft}[0.4 \mathrm{~m}])$ of fine- to medium-grained quartz glauconite sand with scattered broken shells and dark brown phosphate is present at the boundary where this formation unconformably overlies the Manasquan Formation. The interval 857-862 ft (261.3-262.8 m) comprises two glauconite sand beds. Miller, et al. (1994) placed the formational boundary at the lower bed, whereas Browning et al. (Chapter 16, this volume) and this report place it at the upper bed. Placing the contact at the upper bed preserves the Shark River Formation as a middle Eocene unit (i.e., $857 \mathrm{ft}$ is middle Eocene whereas $862 \mathrm{ft}$ is lower Eocene). A couplet of large spikes on the gamma-ray downhole $\log$ is associated with these beds. The basal bed is overlain by a very fine-grained glauconite quartz sandy clay-silt, which is finely bedded to laminated and pale yellowish green and extends upsection to $800 \mathrm{ft}(243.9 \mathrm{~m})$. Indurated silicified layers and large concentrations of foraminifers are common in this clay-silt interval. Interstratified clayey fine- to medium-grained quartz glauconite sands and clayey silts $(\sim 31 \mathrm{ft}$ thick $[9.5 \mathrm{~m}])$ that overlie these lower clay-silt beds are thinly bedded and olive brown. Small, thin-walled macrofossils are present locally in the glauconite beds. The upper $19 \mathrm{ft}$ (5.8 $\mathrm{m}$ ) of the formation consists of a clayey (very calcareous) glauconite quartz sand. Fine pebbles (to $1 \mathrm{~cm}$ diameter) are present in the base of the quartz sand interval (761.5-769 ft [232.2-234.5 m]). The inclusion of this upper quartz sandy interval in the Shark River Formation is based on the transitional nature between the glauconite sand facies and the upper quartz sandy facies. Similar associations were noted in a number of wells in the vicinity of Toms River, a short distance to the northwest of Island Beach. Miller, et al. (1994) lumped this sequence with other upper Eocene strata rather than with the Shark River Formation. Browning et al. (Chapter 16, this volume) assign this unit to the Toms River Member. It contains stratigraphically mixed faunal and floral assemblages (Miller, et al., 1994) and may reflect the effects of a nearby bolide impact (Poag and Aubry, 1995).

Petrology: Except the upper quartz sandy facies (= the Toms River Member of Enright [1969] and Browning et al. [Chapter 16, this volume]), the clay minerals in most of the Shark River Formation are similar to the clay assemblages in the upper Manasquan Formation and are composed of dominant illite/smectite with smaller amounts of illite. Clinoptilolite is also present in lesser amounts. The upper quartz sandy beds have significant amounts of kaolinite in addition to illite/smectite and illite. Clinoptilolite was not found in these upper beds. Enright (1969) found a similar distribution of clinoptilolite in the Manasquan and Shark River Formations to the north.

Environment of deposition: The facies succession of the Shark River Formation include a basal transgressive lag (thin glauconite quartz sand) overlain by a deep-water (probably outer neritic) laminated clay-silt facies. The clay-silt facies is similar in many respects to the Manasquan Formation, but represents a slightly more proximal setting indicated by the higher percentage of very fine-grained glauconite quartz sand. This lower facies grades upward into thinly interbedded very fine- to medium-grained quartz glauconite sands and clay-silts. Small, thin-walled calcareous mollusks and foraminifers are common in this interval. The abundance of medium-grained glauconite, the increase in bedding thickness, and the appearance of small thin-walled mollusks indicates a shallower water depositional site for these beds, most likely in the middle neritic environment. From these observations, the Shark River in this borehole is interpreted to represent a transgressive/regressive cycle. Although the Shark River For- mation is an unconformity-bounded unit, it can be divided into three or four smaller scale sequences using integrated stratigraphy (Browning et al., Chapter 17, this volume).

Age and distribution: Both the calcareous nannofossils and the planktonic foraminifers were examined in the Island Beach borehole. Calcareous nannofossils indicate that the Shark River Formation is middle Eocene to lower upper Eocene (Zones NP14-lower NP18), the same age assigned to this formation in the ACGS\#4 borehole (Owens et al., 1988). The Shark River Formation was one of the more poorly defined formations until recently. Enright (1969) proposed a two-member subdivision: an upper clastic unit only found in the subsurface (the Toms River Member), and a lower argillaceous glauconite sand, which he named the Squankum Member for outcrops along Squankum Creek near Farmingdale, NJ. To better understand the Shark River Formation, the New Jersey Survey drilled a hole at Allaire State Park in 1988, 3.5 km (2.1 mi) south of the Shark River Formation outcrop belt (Sugarman et al., 1991). In Enright's view, the Squankum Member was glauconitic at the top and graded downward into the underlying silty clay Deal Member of the Manasquan Formation. The Shark River Formation at Allaire differs from his description in having common glauconite sand throughout, especially in its lowermost part, although it is quite silty. In addition, it is much more shelly in its upper beds than the Manasquan Formation, which in fact has no obvious macrofossils. The shelly nature of the upper Shark River beds and nonshelly nature of the lower Shark River beds at Allaire is similar to the lithologic associations at Island Beach. We interpret the lower beds as deeper water and the upper beds as shallower at both sites.

Miller, et al. (1994) and Browning et al. (Chapter 16, this volume) recognize both a lower and upper Shark River Formation at Island Beach separated by an unconformity at $800 \mathrm{ft}$ (243.9 m; Fig. 2). The latter study addresses in detail the correlations of this formation among outcrops, the Allaire borehole, and the Island Beach borehole.

\section{Absecon Inlet Formation}

A newly named unit, the Absecon Inlet Formation, lies between 697 and $750 \mathrm{ft}(212.5$ and $228.6 \mathrm{~m}$ ) in the Island Beach borehole (Fig. 2). The type section is in the Atlantic City borehole (Browning et al., Chapter 18, this volume). The Absecon Inlet Formation unconformably overlies the Shark River Formation along a sharp contact overlain by a clayey fine- to medium-grained quartz glauconite sand. There is no spike in the gamma-ray log along this contract, although there is a general increase in radiation across the basal contact (Fig. 2). The lower $33 \mathrm{ft}(10.1 \mathrm{~m})$ of the Absecon Inlet Formation consists of brownish gray to olive-gray, crudely bedded, clayey very fine to medium quartz glauconite sand. Clay beds interbedded with fine- to medium-grained quartz glauconite sands are present in the upper 18 $\mathrm{ft}(5.5 \mathrm{~m})$. The upper $2 \mathrm{ft}(0.6 \mathrm{~m})$ of this interval are grayish orange pink to light brown. The upper contact with the overlying unit is burrowed. The burrows are less than $2 \mathrm{~cm}(0.8 \mathrm{in})$ and are filled with dark green glauconite sand (fig.10 in Miller, et al., 1994). The Absecon Inlet Formation is an unconformity-bounded unit.

Petrology: The clay minerals in the Absecon Inlet Formation are principally illite/smectite with less, but nearly subequal amounts of kaolinite and illite. There is a marked change in the upper pink zone where kaolinite is dominant, but illite/smectite is still present in high concentrations. Illite is also present.

Environment of deposition: The major lithofacies of the Absecon Inlet Formation is a clayey quartz glauconite sand with clay interbeds in the upper part. The lithologic characteristics of the Absecon Inlet Formation are typical of middle neritic deposition, and this is supported by benthic foraminiferal biofacies studies (Browning et al., Chapter 16, this volume). However, the brown color is most common in inner neritic environments, and the pink color may indicate a subaerial weathering. Nevertheless, the presence of calcareous foraminifers and pyrite argues against a subaerial origin for the pinkish color. 
Similarly, the absence of woody fragments and sand-sized mica in the brownish beds argues against an inner neritic environment. We interpret the colors to reflect introduction of the near-shore continental debris into the middle neritic zone, analogous to the introduction of large quantities of kaolinite into the middle neritic environment at the Paleocene/Eocene boundary in the New Jersey Coastal Plain (Gibson et al., 1993). In the latter case, this anomaly was interpreted as evidence of a marked climatic change (much wetter) in the source lands. A similar climatic change is associated with the top of the Absecon Inlet Formation, which is associated with a disconformity spanning the Eocene/Oligocene boundary. A well-documented floristic change to cooler climate species occurred from the late Eocene into the early Oligocene in the region (Frederiksen, 1980; Wolfe, 1985; and Ager in Owens et al., 1988), reflecting global climate change (Miller et al., 1991).

Age and distribution: As in the other Paleogene formations, the age of the Absecon Inlet Formation was determined from its calcareous nannofossil and planktonic foraminiferal content. The nannofossil zones in this unit range from upper Zone NP18 through lower Zone NP21 (essentially all of the upper Eocene). The planktonic foraminifers indicate Zones P15-17 (Miller, et al., 1994; Liu et al., Chapter 10, this volume). Studies subsequent to the Initial Reports (Miller, et al., 1994) show that the highest occurrence of Hantkenina marks the top of the Eocene at $698 \mathrm{ft}(212.8 \mathrm{~m})$ at the top of the formation (Liu et al., Chapter 10, this volume). This indicates that the formation is entirely upper Eocene. Prior to 1988, upper Eocene beds were not known to exist in New Jersey north of Cape May (Owens et al., 1988). This situation resulted from the lack of cored wells in the coastal plain. Owens et al. (1988) obtained a thick upper Eocene section at the ACGS\#4 borehole and used the provisional term ACGS Alpha unit.

\section{Sewell Point Formation}

The lower contact of the newly named Sewell Point Formation (Pekar et al., Chapter 8, this volume) is at $697 \mathrm{ft}(212.5 \mathrm{~m})$ in the Island Beach borehole (Fig. 2). The upper contact is uncertain at Island Beach, occurring either at 602 (183.5 m; Pekar et al., Chapter 8, this volume) or $657 \mathrm{ft}$ (200.3 m; J.P. Owens, unpubl. data; Fig. 2). Pekar et al. (Chapter 8, this volume) stratotypified Oligocene clayey glauconite sand and clayey glauconitic silts and fine-grained quartzose sands as the Sewell Point Formation at the Cape May borehole. At Island Beach, the basal contact is sharp and burrowed. There is no spike on the downhole gamma-ray log between this formation and the underlying unit, although there is a clear general increase in radiation at the base of the Sewell Point Formation (Fig. 2). The Sewell Point Formation is a massive, highly bioturbated, dark greenish black, clayey fine-grained quartz-glauconite sand at Island Beach. Scattered small shell fragments and foraminifers are present. Small pyritized disks (diatoms?) are very common in a few samples. Lignite is not present here, but is common in this unit at the ACGS\#4 borehole.

Pekar et al. (Chapter 8, this volume) place the upper contact of this formation at $602 \mathrm{ft}(183.5 \mathrm{~m})$ based on integrated correlations. J.P. Owens (unpubl. data) places the lithologic contact at $657 \mathrm{ft}(200.2 \mathrm{~m})$ at the base of a section containing weathered brown glauconites. First reported by Olsson et al. (1980), these intriguing brown glauconite sands are a distinct "middle" Oligocene lithology in the New Jersey subsurface. K.G. Miller (unpubl. data, 1978) found that the "glauconite" at the Jobs Point, NJ, borehole had been weathered to goethite and an undifferentiated clay mineral. The dissolving goethite leaches iron into the pore waters. Hansen (1974) found similar brown goethite pellets in the upper Paleocene Aquia Formation of Maryland, a primarily inner neritic deposit. They interpreted it as a biotic product rather than a weathering product. Pekar et al. (Chapter 8 , this volume) interpret these weathered glauconites as recycled detrital minerals deposited in the highstand systems tracts of upper Oligocene sequences at Cape May, Atlantic City, and Jobs Point.

Petrology: All of the major clay minerals occur in this formation. Compared to the underlying Sewell Point Formation, the kaolinite content decreases markedly. Illite/smectite is the major mineral in the lower part of the formation, whereas illite is abundant in the upper beds.

Environment of deposition: The major lithofacies of the Sewell Point Formation is clayey glauconite sand. The lithofacies characteristics of the Sewell Point Formation point to a middle neritic depositional environmental. These characteristics include a dark-gray color, massive bedding due to bioturbation, abundant glauconite, rare shell fragments, low concentrations of foraminifers, low to high concentrations of fine-grained quartz, and a three-mineral clay assemblage.

Age and distribution: Beds of Sewell Point Formation age were unknown in the New Jersey Coastal Plain north of Cape May prior to 1988 (Owens et al., 1988) when they were first recognized as the informal Mays Landing unit at the ACGS\#4 borehole, although Olsson et al. (1980) recognized possible upper lower Oligocene strata. The age of the Sewell Point Formation is not as well constrained at Island Beach as it is elsewhere. At Island Beach, it is assigned to Zone NP22 at the base and undifferentiated Zones P18-19 throughout; Srisotopic ages of ca. $31.5 \mathrm{Ma}$ indicate that the long reversed interval in the formation at this borehole is Chron C12r or C11r (Pekar et al., Chapter 15, this volume). The Sewell Point basin is mainly in southern New Jersey, and the Island Beach borehole establishes the northernmost known occurrence of this formation. The ACGS\#4 borehole lies near the western boundary of the basin. The formation at Island Beach appears to be a thin, truncated unit. Apparently, the Sewell Point Formation was severely beveled in this region.

\section{Atlantic City Formation}

The Atlantic City Formation occurs between $508 \mathrm{ft}(154.8 \mathrm{~m})$ and 602 or $657 \mathrm{ft}(183.5$ or $200.3 \mathrm{~m})$ in the Island Beach borehole (Fig. 2 ). This is a newly defined formation that is stratotypified at the Atlantic City borehole (Pekar et al., Chapter 8, this volume). This formation was informally called the ACGS Beta unit in the ACGS\#4 borehole (Owens et al., 1988). The Atlantic City Formation at Island Beach is a massive to thick-bedded, locally fossiliferous, somewhat clayey, very fine- to coarse-grained quartz (typically less than 20\%) glauconite sand. Other characteristics are poorly sorted sands ranging from very fine-grained to coarse-grained, high concentrations of "glauconite" of the types described above, low kaolinite content, widespread sideritization, and locally large fossils. As noted above, J.P. Owens (unpubl. data) and Pekar et al. (Chapter 8, this volume) place the lower boundary of this unit at 657 and $602 \mathrm{ft}$, respectively. There is also a slight difference in the placement of the upper boundary, with J.P. Owens (unpubl. data) placing it at the base of a glauconite sand at $508 \mathrm{ft}$ and Miller, et al. (1994) placing it at the base of the shelly chocolate clays at $505.5 \mathrm{ft}$. We follow the former in placing the lithologic (and sequence) boundary at $508 \mathrm{ft}$, because glauconite sands mark the base of the overlying Kwla sequence at Atlantic City (Miller and Sugarman, 1995; Fig. 2), and it is reasonable to assume that this pattern of glauconite sands and chocolate clays is correlative at Island Beach.

There are characteristic color variations in the Atlantic City Formation. The lower $65 \mathrm{ft}(19.8 \mathrm{~m})$ is dark gray (Pekar et al. [Chapter 8 , this volume] assign this section to the Sewell Point Formation), the overlying $75 \mathrm{ft}(23 \mathrm{~m})$ is a light olive-brown, and the upper $22 \mathrm{ft}(6.8$ $\mathrm{m}$ ) is olive gray. Siderite cementation is common throughout the formation, especially in the light olive-brown beds. The grains in the light olive-brown beds are unusual for the coastal plain. Although referred to here as glauconite, there are two major color varieties, moderate yellowish brown and grayish green. The green grains in the 
green beds are the mineral glauconite, whereas the brown grains in the olive brown beds are glauconite weathered to goethite.

Petrology: The clay mineral suite in the Atlantic City Formation is dominated by illite/smectite and illite. Kaolinite is present only in low concentrations or is absent altogether.

Environment of deposition: The major lithofacies of the Atlantic City Formation is clayey quartz glauconite sand. Certain lithofacies characteristics indicate an inner neritic origin formed below wave base. However, there are anomalies to such an interpretation, especially mixing of the green glauconite with the brown "glauconite." In situ green glauconites are generally restricted to middle to outer neritic environments (McRae, 1972). As noted above, we interpret much of the glauconite in this unit as reworked, explaining their presence in an inner neritic deposit.

There are several other puzzling aspects in the lithofacies of the Atlantic City Formation at Island Beach. Widespread sideritization in the Atlantic City Formation is a puzzle. The only other coastal unit that has widespread siderite cement is the Upper Cretaceous Tinton Formation (Owens and Sohl, 1969). In the case of the Tinton Formation, the "glauconite" grains are green oolitic forms, not the brown variety found in the Atlantic City Formation. The low concentration of quartz clasts is also puzzling. The upper Oligocene sections at the ACGS\#4 and Jobs Point boreholes contain abundant quartz (Olsson et al., 1980; Owens et al., 1988). Lastly, most of the near-shore coastal plain formations typically have high concentrations of kaolinite, which contrasts with the low kaolinite content of the Atlantic City Formation at Island Beach. The most likely explanation for the very low concentration of kaolinite in the Atlantic City Formation is that kaolinite was only a minor species in the sourcelands, and an inner neritic interpretation is favored.

Age and distribution: Nannofossils and planktonic foraminifers do not provide a definitive age for this unit at Island Beach (Miller, et al., 1994). A Sr-isotopic age in the upper part of the section of 24.3 Ma indicates deposition near the Oligocene/Miocene boundary, although this age estimate is tentative (see Miller, et al., 1994 for Srisotopic methods and discussion). The Atlantic City Formation basin lies in the southern coastal plain. The formation is present in the ACGS\#4, Atlantic City, and Cape May boreholes, but not much is known about the distribution of this unit north of the Island Beach site.

\section{NEOGENE FORMATIONS \\ Kirkwood Formation}

Owens et al. (1995a, 1995b) recently redefined the Kirkwood Formation, previously recognized as the lower to middle Miocene sands and clays in New Jersey (e.g., Sugarman et al., 1993). They recognized four formations increasing in age: Belleplain, Wildwood, Shiloh Marl, and Kirkwood, equivalent to the Kirkwood 3, Kirkwood $2 \mathrm{a}$ and $2 \mathrm{~b}$, Kirkwood 1b, and Kirkwood 1a and Kirkwood 0 sequences, respectively, of Sugarman et al. (1993), Miller and Sugarman (1995), and Sugarman and Miller (1997). In this paper, we retained the older use of the Kirkwood Formation and applied Owens et al.'s (1995a, 1995b) terminology as members of the Kirkwood Formation (Fig. 2; see Miller et al. [Chapter 14, this volume] for discussion). Miller et al. (Chapter 14, this volume) name the most widespread unit the Brigantine Member, which corresponds to the Kirkwood Formation in the restricted sense of Owens et al. (1995a, 1995b).

\section{Kirkwood Formation, Brigantine Member (Kw1a sequence)}

At Island Beach, the Brigantine Member of the Kirkwood Formation (303-507 ft [92.4-154.6 m]) is marked by a sharp contact with the underlying Atlantic City Formation (Fig. 2). A 3-ft (0.9 m) bed of dark green clayey medium-grained quartz glauconite sand with common granules of quartz and scattered large shells represents a re- worked zone along the boundary. All the glauconites in this interval are dark green. There is no gamma-ray spike at the boundary in the downhole geophysical logs, although there is a moderate increase in radiation at the base of the Brigantine Member (Fig. 2). The basal reworked zone is overlain by predominately dark grayish brown silty clay to $430 \mathrm{ft}(131.1 \mathrm{~m})$ and a predominantly fine to medium bioturbated micaceous glauconite quartz sand to $358 \mathrm{ft}$ (109.1 m). There are no mollusks, calcareous nannofossils, foraminifers, or diatoms in these beds. The upper $55 \mathrm{ft}(16.8 \mathrm{~m})$ consists of thinly bedded to laminated thin beds of dark grayish brown woody clays and fine- to medium-grained micaceous quartz sands. Locally, there are thin beds of fine gravely (0.3-mm maximum diameter) medium to coarse quartz sands. These upper beds are also unfossiliferous. The Brigantine Member is an unconformity-bounded unit, corresponding to the Kw1a sequence of Miller and Sugarman (1995) and Sugarman et al. (Chapter 12, this volume).

J.P. Owens (unpubl. data) places the contact between the Kw1a sequence (= the Brigantine Member) and the Kw1b sequence (= Shiloh Member) at $303 \mathrm{ft}(92.4 \mathrm{~m})$. Miller (Chapter 1, this volume) places the contact at $279 \mathrm{ft}(85.0 \mathrm{~m})$ at the base of the uniform chocolate silty clays. No age control is available to help resolve the placement of this boundary, and the downhole gamma-ray logs show no major kicks at either level (Fig. 2).

Petrology: All major clay minerals are present in this member. Illite/smectite is the dominant mineral in the lower half of the member. Kaolinite increases in the upper half and is the major species in the uppermost beds. Opaque heavy minerals are dominated by ilmenite. Nonopaque minerals are dominated by zircon with lesser tourmaline, garnet, staurolite, and sillimanite. Light minerals are quartz with less than $10 \%$ feldspar.

Environment of deposition: The Brigantine Member of the Kirkwood Formation consists of three major lithofacies: a thin basal quartz glauconite sand, a medial thick sandy silt, and an upper quartz sand. Lithofacies characteristics indicate a marine depositional environment for the unit as a whole. The lower portion was deposited in inner neritic environments, whereas the upper section was deposited as part of a marine delta, most likely a delta front.

Age and Distribution: Except for megafossils in the lower $20 \mathrm{ft}$ $(6.1 \mathrm{~m})$, the rest of the member has no calcareous fossils. Sr-isotope analysis of the basal calcareous shells yielded ages of 21.4 and 21.6 Ma (early Miocene; Miller, et al., 1994). There is about a 3-m.y. hiatus between this unit and the underlying Atlantic City Formation based on Sr-isotopic age estimates. The Brigantine Member (Kw1a sequence) is a widespread unit that is present along the entire outcrop belt. The extent of the original Brigantine Formation basin is not known because of post-depositional erosion, but this basin was considerably larger than the basin associated with the underlying Atlantic City Formation.

\section{Kirkwood Formation, Shiloh Marl Member (Kw1b sequence)}

The Shiloh Marl Member of the Kirkwood Formation occurs between 182 and $303 \mathrm{ft}(55.5$ and $92.4 \mathrm{~m}$ ) in the borehole (Fig. 2). J.P. Owens (unpubl. data) identified a sharp contact at $303 \mathrm{ft}(92.4 \mathrm{~m})$, with a dark gray massive bioturbated fine- to medium-grained very micaceous quartz sand lying along the boundary. The dark sand from 286 to $303 \mathrm{ft}(87.2-92.4 \mathrm{~m})$ is overlain by a silty sand to $278.7 \mathrm{ft}(89.0$ $\mathrm{m})$, where Miller (Chapter 1, this volume) places the base of the Shiloh Marl Member. This bed is overlain by $23 \mathrm{ft}(6.9 \mathrm{~m})$ of laminated, color-banded (light and dark gray) burrowed clay-silt. Small pieces of carbonized wood are present in these beds. A 3-ft $(0.9 \mathrm{~m})$ bed of quartz granules is interbedded with the clay-silt. Diatoms have been reported from the clay-silts (Miller, et al., 1994). Otherwise, these beds are unfossiliferous. The clay-silts extend to $256 \mathrm{ft}$ (78.1 m) and are overlain by $6 \mathrm{ft}(1.8 \mathrm{~m})$ of medium gray, massive to thinly bedded, somewhat micaceous, unfossiliferous fine- to medium-sized, gray quartz sand. Small pieces of wood are locally abundant in these 
strata. These gray sands are overlain by $68 \mathrm{ft}(20.7 \mathrm{~m})$ of brownish gray, horizontal, thin to thick quartz sand beds with some local cross bedding. The beds are slightly to very micaceous and locally contain thin interbeds of dark gray finely macerated organic debris. These beds have no mollusks, calcareous nannofossils, foraminifers, or diatoms. This whole interval is overlain with a sharp contact by a claysilt. The Shiloh Marl is an unconformity-bounded unit corresponding to the Kw1b sequence of Miller and Sugarman (1995) and Sugarman et al. (Chapter 12, this volume).

Petrology: The clay minerals in this member are similar to those in the underlying unit with high concentrations of illite/smectite, illite, and kaolinite. Opaque and non-opaque minerals of the Shiloh Marl at Island Beach are similar to those of the underlying Brigantine Member at this borehole.

Environment of deposition: The Shiloh Marl Member of the Kirkwood Formation consists of three major lithofacies: a basal bioturbated, clayey fine quartz sand; a medial thick clay-silt; and an upper less clayey, poorly sorted, fine- to very coarse-grained quartz sand with stray pieces of wood and fine gravel in the upper part. This general lithologic succession is typical of the transgressive (lower part) to regressive (medial and upper parts) sequences found in the coastal plain. The lower transgressive bed contains inner neritic sands at the very base that grade up to prodelta clay-silts above. The upper part contains largely nonmarine coarse clasts with wood as a common component, and we interpret it as fluvial deposit associated with a delta.

Age and distribution: Diatoms collected from the prodelta beds indicate that this unit is lower Miocene at Island Beach (lower East Coast Diatom Zone 2 to East Coast Diatom Zone 1, undifferentiated; Miller, et al., 1994). Other than its stratigraphic position, diatoms are the only way to date this unit at Island Beach. Island Beach approximates the northernmost occurrence of the Shiloh Marl in New Jersey. To the southwest at the ACGS\#4 borehole, the Shiloh Marl is present in the middle of the Kirkwood Formation (between 242 and $381 \mathrm{ft}$ [73.8 and $116.2 \mathrm{~m}$ ] in that hole). The Shiloh Member at the ACGS\#4 borehole has the same general facies succession as at Island Beach: more clayey and fine sands in the base and much less clayey and coarser sands in the upper beds. However, coarse shells are common in these beds, indicating a marine environment at this locality. Similar shell beds are common in upper beds at the type locality near Shiloh, NJ. This indicates a greater marine influence to the south along what should be depositional strike. Minor tectonic differences can account for this shift in deposition to the south.

\section{Kirkwood Formation, Wildwood Member (Kw2a sequence)}

The Wildwood Member (Kw2a sequence) occurs between 78 and $182 \mathrm{ft}(23.8$ and $55.5 \mathrm{~m}$ ) at Island Beach (Fig. 2). This unit unconformably overlies the Shiloh Member along a sharp contact at $182 \mathrm{ft}$ $(55.5 \mathrm{~m})$. There is a gamma ray increase above this boundary in the downhole log (Fig. 2). The basal Wildwood Member is largely a dark brown, laminated to finely cross-bedded very micaceous, finegrained sandy silt that overlies the coarse sands of the underlying unit. The lower silt is overlain by massive, clayey, well-sorted, finegrained, micaceous and woody quartz sand from 158 to $173 \mathrm{ft}$ (48.2$52.7 \mathrm{~m})$. These beds grade into $55 \mathrm{ft}(16.8 \mathrm{~m})$ of moderate brown laminated, slightly to moderately micaceous, woody (typically very small pieces), silty clay with very thin layers of very fine-grained quartz sand that extend to $103 \mathrm{ft}(31.4 \mathrm{~m})$. There are no calcareous fossils in these beds, but diatoms are common to abundant. In the upper $25 \mathrm{ft}(7.6 \mathrm{~m})$, the sand beds increase in number and grain size (with some coarse-grained sands). The upper clay-silts are a very pale gray. This member is unconformably overlain by Holocene deposits. The Wildwood Member is therefore an unconformity-bounded unit corresponding to the Kw2a sequence (Fig. 2) of Miller and Sugarman (1995) and Sugarman et al. (Chapter 12, this volume).

Petrology: The clay minerals in this unit consist mainly of illite/ smectite with lower (but nearly equal) amounts of illite and kaolinite.
In the upper light gray (weathered) beds, illite/smectite decreases markedly, and kaolinite and illite increase. The opaque heavy mineral grains are predominately ilmenite. Nonopaque minerals include zircon, garnet, and sillimanite.

Environment of deposition: The Wildwood Member appears to consist of two major lithofacies: a massive quartz sand at the base and a thicker laminated clay silt at the top. Woody fragments are common in both lithofacies. The only marine fossils found were diatoms in the upper clay silt facies, but the good sorting and common heavy mineral concentrations in the lower sands indicate a near-shore marine depositional environment. The laminated upper beds indicate an inner neritic or prodelta origin. The presence of fine woody fragments, common to abundant mica, and interbeds of sand (probably the result of storm events) favor a prodelta origin for the upper beds.

Age and distribution: The age of this unit was determined by diatoms. The diatom assemblage falls within East Coast Diatom Zone 2 (Miller, et al., 1994) of the zonation proposed by Andrews (1988). This zone is uppermost lower to lowermost middle Miocene. The Island Beach well marks the northern limit of the Wildwood Member. Elsewhere, the Kw2a sequence has been firmly dated as latest early Miocene (Miller and Sugarman, 1995; Sugarman et al., 1993; Sugarman et al., Chapter 12, this volume). This member was penetrated in the ACGS\#4 borehole, where it was included in the uppermost beds of the Kirkwood Formation. The lithology of the Wildwood Member in this borehole is similar to that at Island Beach.

The middle (?) Miocene Cohansey Formation is beveled and not represented at Island Beach (Owens et al., 1995b).

\section{Unnamed Holocene to ?Uppermost Pleistocene Deposits}

Holocene to uppermost (?) Pleistocene deposits occur between 0 and $78 \mathrm{ft}(0$ and $23.7 \mathrm{~m})$ in this borehole (Fig. 2). These beds rest unconformably on the underlying Kirkwood Formation along a sharp contact. There is a 8 -ft-thick $(2.4 \mathrm{~m})$ gravely $(0.02-\mathrm{cm}$ maximum size), poorly sorted, fine- to very coarse-grained, feldspathic quartz sand along this boundary. The sands in this basal bed decrease in grain size upward. This basal bed is represented by a broad gammaray spike in the geophysical log. The overlying $30 \mathrm{ft}(9.1 \mathrm{~m})$ consist of interbedded clays and mostly coarse-grained sand. Many of the sandy beds include glauconite as a component. Shells are also common in this interval. The upper $40 \mathrm{ft}(12.2 \mathrm{~m})$ are primarily fine- to medium-grained sand. Two radiocarbon dates at 24.8 and $58.1 \mathrm{ft}(7.6$ and $17.7 \mathrm{~m}$ ) of 4.5 and $5.6 \mathrm{ka}$ date this sequence as Holocene, although it is possible that it is uppermost Pleistocene at its base (see Miller, et al., 1994 for details of dates). This unit represents a sequence that was deposited during the Holocene transgression as one deepening-upward succession representing fluvial gravels and sands at the base to near-shore facies (well-sorted fine- to medium-grained sands) at the top.

\section{DISCUSSIONS AND CONCLUSIONS}

At the time of his death, the senior author, J.P Owens, had completed a draft of his notes on the Island Beach borehole, but only preliminary notes were completed on the Atlantic City and Cape May boreholes. As a result, the goal of this report, to evaluate the role of tectonics on Cenozoic basins in New Jersey, was not completed. Nevertheless, the detailed lithostratigraphic data and paleoenvironmental interpretations presented here for Island Beach can be compared with outcrops, previously drilled boreholes (ACGS\#4, Clayton, and Allaire; Fig. 2), and various other sources (rotary wells and geophysical logs; Owens et al., 1995a, 1995b). The following observations are based on his comparisons.

Based on these data, we conclude that tectonics reshaped the basins in which Upper Cretaceous to Holocene strata were deposited. Eocene basins were the most extensive areally and represent the deepest water paleoenvironments. Oligocene basins, represented by the Sewell Point and Atlantic City Formations, were more restricted, 
occurring mainly in southern New Jersey (Atlantic City and south). The early Miocene Kirkwood basin was more expansive both updip and along strike to the north. The Brigantine Member of the Kirkwood Formation (the Kw1a sequence) was deposited in the most extensive of the early to middle Miocene basins. Subsequent Miocene basins were more areally restricted and less influenced by marine deposition. In addition, tectonic changes resulted in differential beveling of stratigraphic units and preferential preservation. For example, the lower Oligocene Sewell Point Formation appears to be truncated north of Mays Landing, NJ, and is poorly represented at the Island Beach borehole.

\section{ACKNOWLEDGMENTS}

A draft of this chapter was completed by James P. Owens prior to his untimely death in June 1995, and Miller and Sugarman edited and modified the draft. This report was to present results from all three Leg 150X boreholes and to compare these sites with the other holes discussed above. Unfortunately, only results from the Island Beach report were available at the time of the his death. Based on his written notes and data, Miller and Sugarman derived this chapter. They were responsible for adding and clarifying stratigraphic correlations and for reconciling Owens' observations with previously published results in the Initial Reports (Miller, et al., 1994) and with various studies published in this volume. We do not claim to represent Jim's opinions in their entirety, but have tried to incorporate data derived subsequent to his death into this paper while maintaining the spirit and intent of his original manuscript. As such, there are passages herein that Jim might not agree with, even as there are some with which the junior authors disagree. Despite these inevitable shortcomings, we are happy that Jim's final study could be published and hope that these observations prove of interest. We thank J. Browning and S. Pekar for discussions, F. Pazzaglia for Figure 1, and G. Gohn, M. Katz, F. Pazzaglia for reviews. Supported by NSF Grants EAR9218210 and 94-17108. This is LDEO contribution 5673.

\section{REFERENCES}

Andrews, G.W., 1988. A revised marine diatom zonation for Miocene strata of the southeastern United States. Geol. Surv. Prof. Pap. U.S., 1481:1-29.

Berggren, W.A., Kent, D.V., Swisher, C.C., and Aubry, M.-P., 1995. A revised Cenozoic geochronology and chronostratigraphy. In Berggren, W.A., Kent, D.V., and Hardenbol, J. (Eds.), Geochronology, Time Scales and Global Stratigraphic Correlation: Spec. Publ. Soc. Econ. Paleontol. Mineral., 54:129-212.

Enright, R., 1969. The stratigraphy and clay mineralogy of Eocene sediments of the northern New Jersey coastal plain. In Subitsky, S. (Ed.), Geology of Selected Areas in New Jersey and Eastern Pennsylvania and Guidebook of Excursions: New Brunswick, NJ (Rutgers University Press), 1420.

Frederiksen, N.O., 1980. Sporomorphs from the Jackson group (upper Eocene) and adjacent strata of Mississippi and western Alabama. Geol. Surv. Prof. Pap. U.S., 1084.

Gibson, T.G., Bybell, L.M., and Owens, J.P., 1993. Latest Paleocene lithologic and biotic events in neritic deposits of southwestern New Jersey. Paleoceanography, 8:495-514.

Hansen, H.J., 1974. Sedimentary facies of the Aquia Formation in the subsurface of the Maryland coastal plain. Maryland Geol. Surv., Rep. 21.

McRae, S.G., 1972. Glauconite. Earth-Sci. Rev., 8:397-440.

Miller, K.G., et al., 1994. Proc. ODP, Init. Repts., 150X: College Station, TX (Ocean Drilling Program).

1996a. Proc. ODP, Init. Repts., 150X (Suppl.): College Station, TX (Ocean Drilling Program).

Miller, K.G., Mountain, G.S., Blum, P., Gartner, S., Alm Per, G., Aubry, M.P., Burckle, L.H., Guerin, G., Katz, M.E., Christensen, B.A., Compton, J., Damuth, J.E., Deconinck, J.F., de Verteuil, L., Fulthorpe, C.S., Hesselbo, S.P., Hoppie, B.W., Kotake, N., Lorenzo, J.M., McCracken, S., McHugh, C.M., Quayle, W.C., Saito, Y., Snyder, S.W., ten Kate, W.G., Urbat, M., Van Fossen, M.C., Vecsei, A., Sugarman, P.J., Mullikin, L., Pekar, S., Browning, J.V., Liu, C., Feigenson, M.D., Goss, M., Gwynn, D., Queen,
D.G., Powars, D.S., Heibel, T.D., and Bukry, D., 1996b. Drilling and dating New Jersey Oligocene-Miocene sequences: ice volume, global sea level, and Exxon records. Science, 271:1092-1095.

Miller, K.G., and Sugarman, P.J., 1995. Correlating Miocene sequences in onshore New Jersey boreholes (ODP Leg 150X) with global $\delta^{18} \mathrm{O}$ and Maryland outcrops. Geology, 23:747-750.

Miller, K.G., Wright, J.D., and Fairbanks, R.G., 1991. Unlocking the Ice House: Oligocene-Miocene oxygen isotopes, eustasy, and margin erosion. J. Geophys. Res., 96:6829-6848.

Mountain, G.S., Miller, K.G., Blum, P., et al., 1994. Proc. ODP, Init. Repts., 150: College Station, TX (Ocean Drilling Program).

Olsson, R.K., 1991. Cretaceous to Eocene sea-level fluctuations on the New Jersey margin. Sediment. Geol, 70:195-208.

Olsson, R.K., Miller, K.G., and Ungrady, T.E., 1980. Late Oligocene transgression of middle Atlantic coastal plain. Geology, 8:549-554.

Owens, J.P., 1970. Post-Triassic tectonic movements in the central and southern Appalachians as recorded by sediments of the Atlantic coastal plain. In Fisher, G.W., Pettijohn, F.J., and Reed, J.C., Jr. (Eds.), Studies of Appalachian Geology: Central and Southern: New York (Interscience), 417427.

, 1983. The northwestern Atlantic Ocean margin. In Moullade, M. and Nairn, A.E.M. (Eds.), The Phanerozoic Geology of the World, II: The Mesozoic: New York (Elsevier), 33-60.

Owens, J.P., Bybell, L.M., Paulachok, G., Ager, T.A., Gonzalez, V.M., and Sugarman, P.J., 1988. Stratigraphy of the Tertiary sediments in a 945foot-deep core hole near Mays Landing in the southeastern New Jersey coastal plain. Geol. Surv. Prof. Pap. U.S., 1484.

Owens, J.P., and Gohn, G.S., 1985. Depositional history of the Cretaceous series in the U.S. coastal plain: stratigraphy, paleoenvironments, and tectonic controls of sedimentation. In Poag, C.W., (Ed.), Geologic Evolution of the United States Atlantic Margin: New York (Van Nostrand Reinhold), 25-86.

Owens, J.P., Minard, J.P., and Sohl, N.F., 1968. Cretaceous deltas in the northern New Jersey coastal plain, Trip B. In Finks, R.L. (Ed.), Guidebook to Field Excursions, 40th Ann. Meeting: Flushing, NY (NY State Geol. Assoc.), 33-48.

Owens, J.P., Minard, J.P., Sohl, N.F., and Mello, J.F., 1970. Stratigraphy of the outcroppping post-Magothy Upper Cretaceous formations in southern New Jersey and northern Delmarva Peninsula, Delaware and Maryland. Geol. Surv. Prof. Pap. U.S., 674.

Owens, J.P., and Sohl, N.F., 1969. Shelf and deltaic paleoenvironments in the Cretaceous-Tertiary formations of the New Jersey Coastal Plain. In Subitzky, S. (Ed.), Geology of Selected Areas in New Jersey and Eastern Pennsylvania and Guidebook of Excursions: New Brunswick, NJ (Rutgers Univ. Press), 235-278.

Owens, J.P., Sohl, N.F., and Minard, J.P., 1977. A Field Guide to Cretaceous and Lower Tertiary Beds of the Raritan and Salisbury Embayments, New Jersey, Delaware, and Maryland: Washington, D.C. (AAPG-Soc. Econ. Paleontol. Mineral.).

Owens, J.P., Sugarman, P.J., Sohl, N.F., and Orndorff, R.C., 1995a. Geologic map of New Jersey: Southern Sheet. Open-File Rep.-U.S. Geol. Surv., 95-254.

Owens, J.P., Sugarman, P.J., Sohl, N.F, Parker, R., Houghton, H.H., Volkert, R.V., Drake, A.A., and Orndorff, R.C., 1995b. Geologic map of New Jersey: Central Sheet. Open-File Rep.-U.S. Geol. Surv., 95-253.

Pazzaglia, F.J., 1993. Stratigraphy, petrography, and correlation of late Cenozoic middle Atlantic Coastal Plain deposits: implications for late-stage passive-margin geologic evolution. Geol. Soc. Am. Bull., 105:16171634.

Poag, C.W., and Aubry, M.-P., 1995. Upper Eocene impactites of the U.S. East Coast: depositional origins, biostratigraphic framework, and correlation. Palaios, 10:16-43.

Sugarman, P.J., and Miller, K.G., 1997. Correlation of Miocene global sequences and hydrostratigraphic units, New Jersey coastal plain. Sediment. Geol. 108:3-18.

Sugarman, P.J., Miller, K.G., Bukry, D., and Feigenson, M.D., 1995. Uppermost Campanian-Maastrichtian strontium isotopic, biostratigraphic, and sequence stratigraphic framework of the New Jersey coastal plain. Geol. Soc. Am. Bull., 107:19-37.

Sugarman, P.J., Miller, K.G., Owens, J.P., and Feigenson, M.D., 1993. Strontium isotope and sequence stratigraphy of the Miocene Kirkwood Formation, southern New Jersey. Geol. Soc. Am. Bull., 105:423-436.

Sugarman, P.J., Owens, J.P., and Bybell, L.M., 1991. Geologic map of the Adelphia and Farmingdale Quadrangles, Monmouth and Ocean Counties, New Jersey. NJ Geol. Surv., Geol. Map Series, 91-1. 
Wolfe, J.A., 1985. Distribution of major vegetational types during the Tertiary. In Sundquist, E.T., and Broecker, W.S. (Eds.), The Carbon Cycle and Atmospheric $\mathrm{CO}_{2}$ : Natural Variations from the Archean to Present: Am. Geophys. Union Monogr., 32:357-376.
Date of initial receipt: 1 February 1996

Date of acceptance: 14 August 1996

Ms 150XSR-302 